
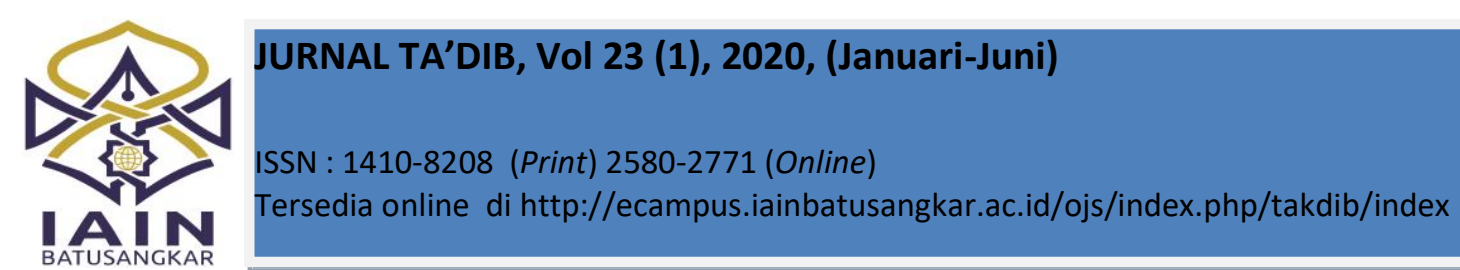

\title{
Mobile Learning pada Mata Kuliah Strategi Pembelajaran MI/SD: Penelitian Pengembangan
}

\section{Nur Hidayah Hanifah}

Universitas Islam Negeri Maulana Malik Ibrahim Malang, Jawa Timur, Indonesia

E-mail: nurhidayahhanifah@uin-malang.ac.id

\section{Imam Rofiki*)}

Universitas Islam Negeri Maulana Malik Ibrahim Malang, Jawa Timur, Indonesia E-mail: imam.rofiki@uin-malang.ac.id

\section{Agung Sedayu}

Universitas Islam Negeri Maulana Malik Ibrahim Malang, Jawa Timur, Indonesia E-mail: uinsedayu@gmail.com

\section{Mokhamad Amin Hariyadi}

Universitas Islam Negeri Maulana Malik Ibrahim Malang, Jawa Timur, Indonesia E-mail: adyt2002@uin-malang.ac.id

*) Corresponding Author

\begin{abstract}
There has been a trend of utilizing mobile tools in the university. This study is proposed to construct mobile learning media based on Android for Madrasah Ibtidaiyah or Primary School in Learning Strategy courses. The study participants were university students of Madrasah Ibtidaiyah Teacher Education in Malang. The study design was $R$ and $D$ with both quantitative and qualitative data. The study result have been in the form of mobile learning media based on Android. Six expert judgments have validated this product to ascertain the feasibility of the designed prototype. The validation by material experts' validation results were $91 \%$ and $89 \%$ valid, while validation rates by design experts were $93 \%$ and $92 \%$. The validation result by learning experts showed $88 \%$ and $89 \%$ valid. The design was tested to three students with individual trials, then to a small group trial with ten students, and finally, a field trial on an experimental class of 43 students using a questionnaire. The trials' result on small groups showed $88 \%$ valid, and the field trials showed $86 \%$ valid. The findings indicated that Androidbased mobile learning on learning strategy course material had a better effect than conventional learning on student learning outcomes.
\end{abstract}

Keywords: Development, Mobile Learning, Android, Learning Strategy, Learning Media, ADDIE

\section{PENDAHULUAN}

$\mathrm{P}$ elaksanaan pembelajaran yang menggunakan teknologi informasi dan komunikasi sangat penting di era milenial ini. Pendidik harus mempunyai inovasi baru dalam kegiatan pembelajaran guna menunjang pembelajaran yang inovatif dan interaktif. Smartphone berbasis android sudah banyak digunakan oleh mahasiswa. Proses pembelajaran perlu memanfaatkan alat tersebut untuk pengembangan sebuah media mobile learning yang memungkinkan peserta didik bisa mengakses sendiri (self contained) materi pembelajaran, yaitu dalam bentuk pembelajaran aplikasi mobile. Aplikasi mobile sangat penting untuk digunakan dalam pembelajaran terutama untuk mata kuliah wajib seperti strategi pembelajaran yang harus dikuasi mahasiswa baik materi ataupun praktiknya (Hamidi \& Chavoshi, 2018; Jeno dkk., 2019; Pocatilu, 2010; Skiada dkk., 2014). Hal ini dapat menunjang terlaksananya proses pembelajaran yang menarik.

Media pembelajaran yang ditanamkan pada perangkat smartphone memiliki kelebihan tersendiri. Media tersebut dapat dimanfaatkan kapanpun dan di manapun (Amelia dkk., 2020; Hao dkk., 2019; Mallya \& Srinivasan, 2019; Motiwalla, 2007; Suana dkk., 2019). Bentuk fisiknya yang relatif kecil membuat perangkat ini dapat dibawa ke manapun. Sehingga mahasiswa dapat belajar secara mandiri baik di rumah ataupun di lingkungan kampus. Dalam pengembangan media pembelajaran pada platform 
smartphone ini diperlukan observasi awal untuk menganalisis kebutuhan apa yang diinginkan oleh sebuah instansi.

Dengan dikembangkannya sebuah media mobile learning berbasis android ini bisa menjadi suplemen bagi mahasiswa dalam belajar serta mempermudah dosen untuk menyampaikan materi kepada mahasiswa. Media mobile learning juga dapat membantu mahasiswa untuk menyiapkan, menerima dan mempraktikkan materi (Gikas \& Grant, 2013; Hafidz dkk., 2019; Saputra dkk., 2018).

Pada Abad 21 ini, siswa/mahasiswa perlu mengembangkan pengetahuan secara mandiri, kreatif, dan mahir (Suryani dkk., 2020). Pelibatan media berbasis teknologi dalam pembelajaran perlu diterapkan untuk menjawab tantangan di era masa kini (Muchlis \& Putra, 2017; Rahmi, 2019; Rosikhoh dkk., 2019). Pengonstruksian media harus menarik sehingga mahasiswa merasa senang belajar. Ketika mahasiswa kurang memahami suatu materi tertentu, mahasiswa tersebut dapat mempelajari materinya di mana saja. Kurangnya variasi media pembelajaran bukan disebabkan kesalahan dosen, akan tetapi karena waktu pembelajaran di kelas yang terbatas, kondisi lingkungan belajar, karakter mahasiswa, dan kurangnya pemanfaatan perkembangan teknologi secara optimal.

Pengembangan dan pemanfaatan teknologi seperti mobile learning menjadi tren penelitian saat ini. Park (2011) membuat kerangka pedagogis untuk mobile learning. Hamidi \& Chavoshi (2018) menyelidiki dampak penggunaan mobile learning pada pendidikan tinggi. Angkotasan dkk. (2019) mengembangkan media online berbasis Kahoot sebagai alat evaluasi pembelajaran. Li dkk. (2019) menginvestigasi pengaruh mobile learning pada mahasiswa pendidikan. Namun, beberapa penelitian terdahulu belum membuat dan mengujikan mobile learning berbasis android pada perguruan tinggi. Sehingga peneliti ingin mengembangkan media pembelajaran untuk mahasiswa Pendidikan Guru Madrasah Ibtidaiyah pada mata kuliah Strategi Pembelajaran berupa mobile learning. Penelitian ini memberikan kontribusi signifikan bagi para pendidik sebagai media pembelajaran yang efektif dan mudah digunakan oleh mahasiswa.

\section{METODE PENELITIAN}

Penelitian ini termasuk Research and development yang disebut juga penelitian pengembangan dengan penggunaan model ADDIE (Branch, 2009; Kristanti dkk., 2018). Terdapat lima tahapan dalam model pengembangan ADDIE, yaitu: Analisis (Analysis), Perancangan (Design), Pengembangan (Development), Implementasi (Implementation), dan Evaluasi (Evaluation). Pembuatan aplikasi media mobile learning menggunakan software Android Studio 3.4.

1. Partisipan dan Waktu Penelitian

Penilitian ini melibatkan calon guru (mahasiswa) Pendidikan Guru Madrasah Ibtidaiyah di Malang yang menempuh mata kuliah Strategi Pembelajaran MI/SD. Penelitian ini dilaksanakan selama 3 bulan pada semester gasal tahun 2019/2020.

2. Jenis dan Sumber Data

Penelitian ini menggunakan data kualitatif dan data kuantitatif. Data kualitatif dikumpulkan berdasarkan tanggapan, masukan, kritik hasil penilaian, dan saransaran perbaikan melalui angket pertanyaan terbuka kepada para expert judgement, yaitu ahli materi, ahli desain, dan ahli pembelajaran. Data kuantitatif berbentuk angka yang dikumpulkan dari angket pertanyaan tertutup berupa poin-poin pertanyaan terstruktur yang berisikan penilaian media yang dikembangkan dari segi pembelajaran, materi, tampilan, dan bahasa yang digunakan serta perolehan nilai hasil belajar mahasiswa setelah menggunakan media pembelajaran.

3. Teknik Pengumpulan Data

Pengumpulan data dalam penelitian ini menggunakan lembar validasi dan angket kuesioner.

4. Desain Uji Coba

True experimental dalam matching pretest - post test comparison group design (Effendi, 2013) dipakai sebagai desain uji 
coba untuk penelitian pengembangan ini. Penelitian ini menggunakan tes hasil belajar sebanyak dua kali untuk mengukur ranah kognitif mahasiswa. Tes pertama bertujuan untuk mengetahui kemampuan kognitif kedua kelompok sedangkan tes kedua bertujuan untuk mengukur hasil belajar siswa. Desain eksperimen dalam penelitian ini disajikan pada Tabel 1.

Tabel 1. Matching pretest-postest control group

\begin{tabular}{llll}
\multicolumn{4}{c}{ design } \\
\hline Kelompok & Pre-test & Perlakuan $(\mathrm{X})$ & Post-test \\
\hline $\mathrm{KE}$ & $\mathrm{O}_{1}$ & $\mathrm{X}_{1}$ & $\mathrm{O}_{2}$ \\
$\mathrm{KK}$ & $\mathrm{O}_{3}$ & $\mathrm{X}_{2}$ & $\mathrm{O}_{4}$ \\
\hline
\end{tabular}

Keterangan:

$\mathrm{KE}=$ Kelompok eksperimen

$\mathrm{KK}=$ Kelompok kontrol

$\mathrm{O}_{1}=$ Pre - test kelompok eksperimen

$\mathrm{O}_{\mathrm{a}}=$ Pre - test kelompok kontrol

$\mathrm{X}_{1}=$ Pembelajaran mobile berbasis Android

$\mathrm{X}_{2}=$ Pembelajaran konvensional

$\mathrm{O}_{2}=$ Post - test kelompok eksperimen

$\mathrm{O}_{4}=$ Post - test kelompok kontrol

\section{Teknik Analisis Data}

Pengembangan media ini menggambarkan dan mempresentasikan secara rinci sesuai dengan informasi data yang didapatkan dan dikumpulkan dari hasil angket serta pencapaian tes hasil belajar yang selanjutnya akan diterjemahkan ke dalam pengembangan media pembelajaran berbasis android yang cocok dengan kebutuhan mahasiswa. Teknis analisis data menggunakan cara sebagai berikut.

a. Kualitatif

Data kualitatif dilaksanakan uji coba, data untuk memperoleh penilaian untuk menerima saran, kritik, dan input dalam rangka perbaikan. Untuk menguji tingkat ketepatan, respons penggunaan media pembelajaran dapat menggunakan hasil dari analisis deskriptif.

b. Kuantitatif

Data kuantitatif dari angket para ahli yang dihimpun berupa angka-angka yang selanjutnya diolah dan dianalisis dengan deskriptif persentase menggunakan rumus berikut.

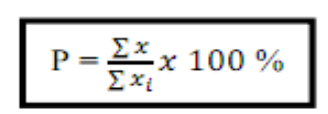

$\mathrm{P}=$ Kelayakan

$\sum_{x}=$ Jumlah jawaban penilaian
$\sum_{x_{i}}=$ Jumlah jawaban tertinggi

Tabel 2. Kualifikasi tingkatan kelayakan berdasarkan persentase

\begin{tabular}{ccc}
\hline Persentase $(\%)$ & Kriteria Kelayakan & Keterangan \\
\hline $90<$ nilai $\leq 100$ & Sangat Valid & Tidak Revisi \\
& & \\
$80<$ nilai $\leq 90$ & Valid & Tidak Revisi \\
$70<$ nilai $\leq 80$ & Cukup Valid & Sebagian \\
& & Revisi \\
$60<$ nilai $\leq 70$ & Kurang Valid & Revisi \\
nilai $\leq 60$ & Sangat Kurang & Revisi \\
& Valid &
\end{tabular}

c. Uji Asumsi Data Awal

1) Uji Normalitas

Menggunakan uji Shapiro-Wilk dengan taraf signifikansi 0,05 untuk menguji normalitas antara kelas eksperimen dengan kelas kontrol.

2) Uji Homogenitas

Menggunakan uji Levene dengan taraf signifikansi 0,05 untuk menguji homogenitas antara kelas eksperimen dengan kelas kontrol.

6. Analisis Uji Asumsi Data Akhir Uji-T

Pengaruh terhadap suatu perlakuan digunakan dengan Uji-t yang dibebankan terhadap suatu kelompok objek penelitian satu pihak dengan nilai signifikansinya 0,05 yaitu pihak kanan. Sebelum analisis data, peneliti membuat sebuah hipotesis statistik berikut.

$$
\begin{aligned}
& H 0: \mu 1=\mu 2 \\
& H 1: \mu 1 \neq \mu 2
\end{aligned}
$$

Keterangan:

$\mathrm{H}_{0}$ : Tidak terdapatnya perbedaan hasil belajar mahasiswa yang mendapatkan materi dengan menggunakan pembelajaran konvensional dengan nilai hasil belajar mahasiswa yang menggunakan media mobile learning berbasis android

$\mathrm{H}_{1}$ : Nilai hasil belajar mahasiswa yang mendapatkan materi dengan menggunakan media mobile learning berbasis android lebih baik daripada 
nilai hasil belajar pada mahasiswa yang memperoleh pembelajaran konvesional Analisis yang digunakan adalah Uji-t dua variabel bebas dengan rumus yang memiliki tingkat kemaknaan 0,05.

$$
\frac{\overline{X_{1}}-\overline{X_{2}}}{\sqrt{\frac{S_{1}^{2}}{n_{1}}+\frac{S_{2}^{2}}{n_{2}}-2 . r\left(\frac{S_{1}}{\sqrt{n_{1}}}\right)\left(\frac{S_{2}}{\sqrt{n_{2}}}\right)}}
$$

Keterangan:

Keterangan :

$\overline{X_{1}}=$ Rata-rata nilai kelas eksperimen

$\overline{X_{2}}=$ Rata-rata nilai kelas kontrol

$S_{1}^{2}=$ Varians kelas eksperimen

$S_{2}^{2}=$ Varians kelas kontrol

$S_{1}=$ Standar deviasi kelas eksperimen

$S_{2}=$ Standar deviasi kelas kontrol

$n_{1}=$ Jumlah mahasiswa kelas eksperimen

$n_{2}=$ Jumlah mahasiswa kelas kontrol

Hasil uji coba dapat dilihat dengan cara membandingkan hasil uji coba dengan t-tabel dan taraf $5 \%$ sebagai berikut.

$\mathrm{H}_{0}$ : Tidak terdapat perbedaan yang signifikan $(5 \%)$ antara sebelum dan sesudah menggunakan media mobile learning berbasis android

$\mathrm{H}_{1}$ : Terdapat perbedaan yang signifikan $(5 \%)$ antara sebelum dan sesudah menggunakan media mobile learning berbasis android

7. Rencana Pembahasan

a. Analysis

Peneliti melakukan analisis pada pengembangan media pembelajaran berbasis mobile. Kegiatan ini berupa analisis kebutuhan, analisis lingkungan belajar, analisis karakteristik mahasiswa, dan analisis tujuan pembelajaran.

b. Design

Desain disusun dengan mempelajari masalah, kemudian mencari solusi melalui identifikasi dari tahap analisis kebutuhan pada proses sebelumnya. Langkah yang ditempuh pada tahap desain ini adalah menentukan strategi pembelajaran dan pembuatan rancangan media pembelajaran yang diwujudkan dalam bentuk storyboard.

c. Development

Pada tahap ini, peneliti mewujudkan desain menjadi kenyataan. Peneliti menyusun dan merancang mobile learning dari hasil pengumpulan informasi yang telah diperoleh pada tahap sebelumnya.

d. Implementation

Pada tahap ini, mobile learning berbasis android diimplementasikan dalam proses pembelajaran. Tujuan utama dari tahap implementasi yaitu membimbing mahasiswa dalam mencapai tujuan pembelajaran serta memastikan bahwa pada akhir pembelajaran mahasiswa memperoleh suatu kompetensi pengetahuan dan keterampilan.

e. Evaluation

Terdapat dua model evaluasi yang digunakan, yaitu evaluasi formatif dan evaluasi sumatif. Evaluasi formatif dilakukan agar mendapatkan data untuk melakukan revisi bahan terhadap media pembelajaran yang dihasilkan supaya lebih efektif, sedangkan evaluasi sumatif dilaksanakan agar meningkatkan tingkat efektivitas mobile learning berbasis android secara keseluruhan dibanding dengan produk lain.

\section{HASIL DAN PEMBAHASAN}

1. Deskripsi Spesifikasi Produk Media

Pengembangan media pada mata kuliah strategi pembelajaran MI/SD meliputi pra produksi, produksi, dan pasca produksi.

a. Pra Produksi

Ada beberapa penentuan pada tahap pra produksi di antaranya menganalisis capaian pembelajaran dan indikator, mengumpulkan referensi-referensi, memilih gambar dan animasi, membuat storyboard.

b. Produksi

Membuat media mobile learning pada mata kuliah strategi pembelajaran MI/SD 
menggunakan aplikasi Android Studio 3.4 .

c. Pasca Produksi

Pada tahapan ini, peneliti melakukan proses editing yang terakhir serta pengemasan produk secara keseluruhan untuk dipersiapkan ke tahap implementasi.

Produk media mobile learning terdiri dari 6 bagian yaitu, deskripsi bahan ajar, bantuan, materi, video, evaluasi, dan profil pengembang.

Berikut profil singkat dan penjelasan masing-masing bagian produk yang dikembangkan.

Nama Produk : STRAPEL

Software : Android Studio 3.4

Type of File : Apk (Application Package File)

Size on disk : $70 \mathrm{MB}$

\section{Splash Screen}

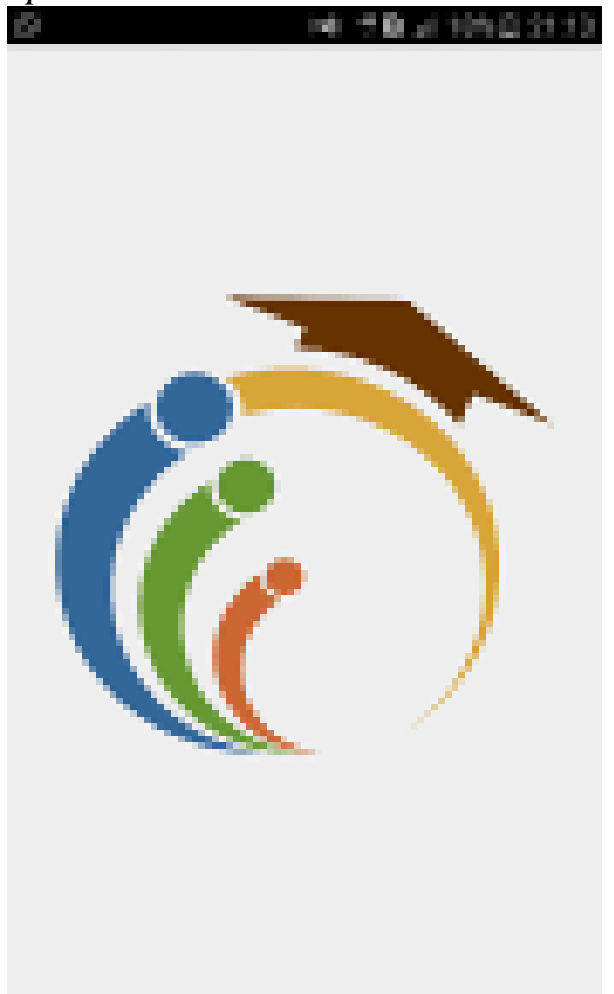

Splash Screen merupakan tampilan awal ketika aplikasi dijalankan. Pada saat membuka aplikasi, logo dari media pembelajaran ini muncul. Splash Screen akan tampil di layar smartphone hanya selama tiga detik sebelum masuk ke menu utama.
2. Menu Utama

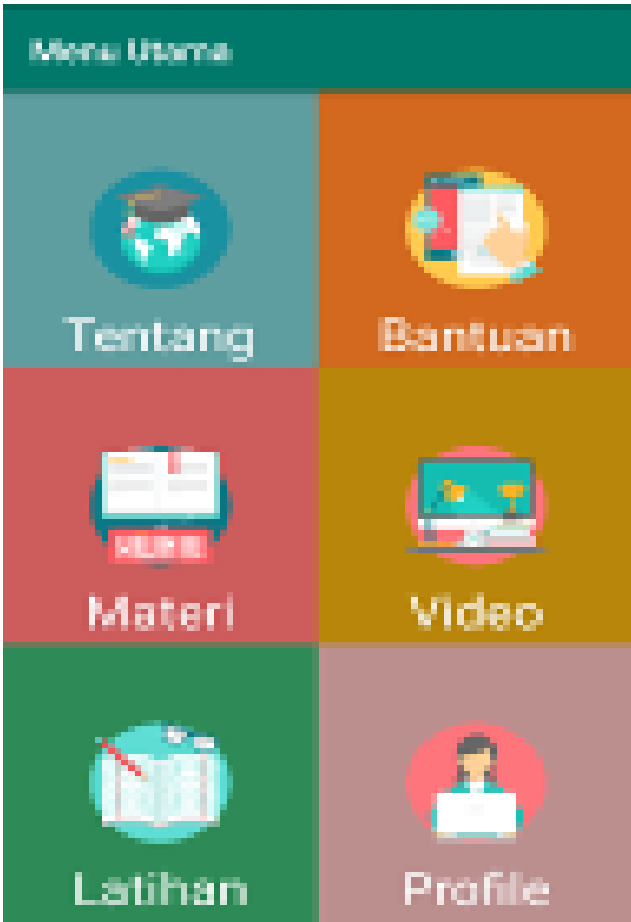

Menu utama merupakan bagian pokok dari media ini. Terdapat enam menu utama yang terdapat di media ini yaitu menu Tentang, Bantuan, Materi, Video, Latihan, dan Profile. Setiap menu dapat dipilih sesuai dengan kebutuhan pengguna media pembelajaran.

3. Menu Daftar Materi

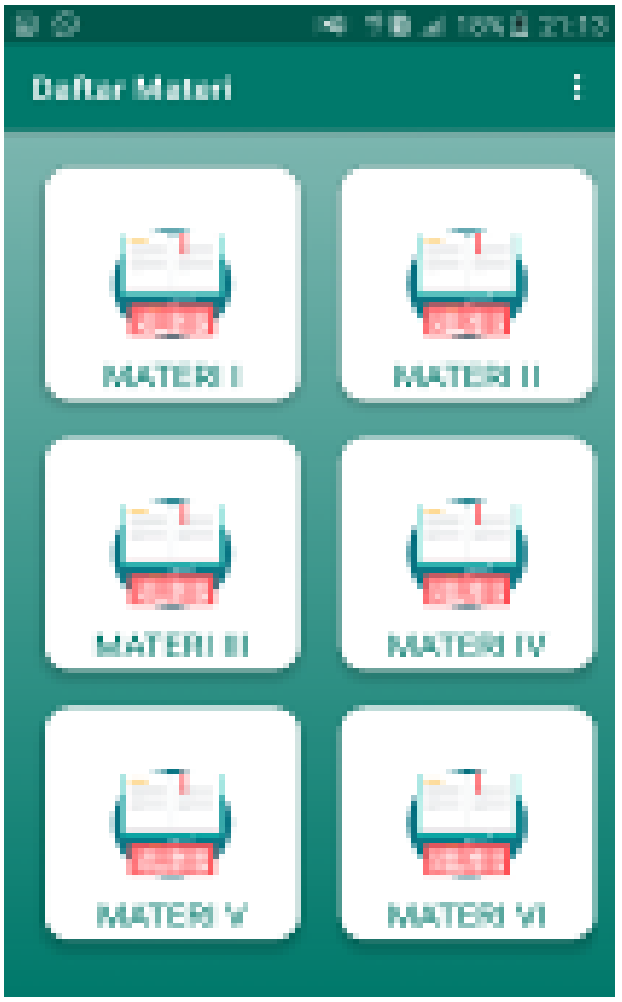


Pada halaman ini ditampilkan enam pilihan materi pembelajaran yang bisa dipelajari oleh mahasiswa. Mahasiswa diberikan kebebasan dalam memilih materi yang ingin dipelajari. Sehingga mahasiswa dapat mengulang materi jika merasa kurang paham.

4. Materi

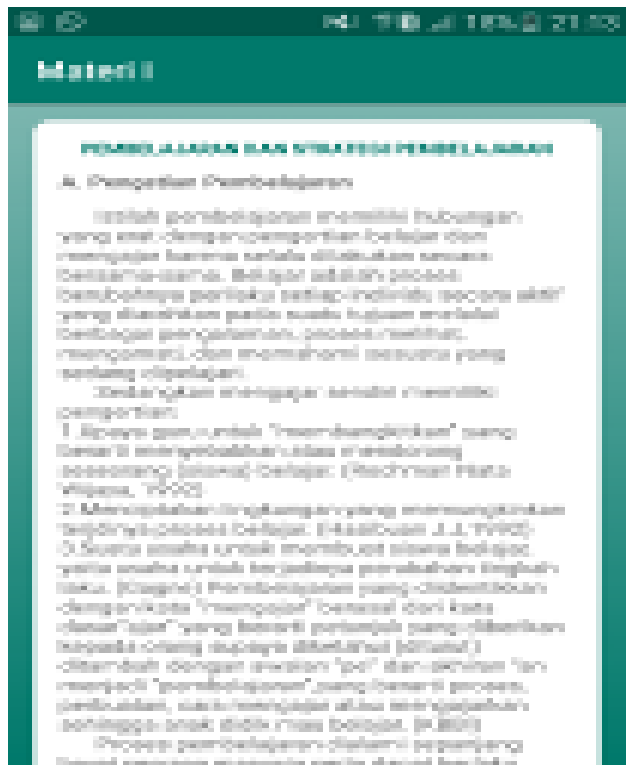

Setelah memilih menu di pilihan materi, maka akan tampil sebuah halaman materi. Siswa dapat membaca dan memahami isi materi. Jika mahasiswa sudah paham, maka mahasiswa bisa membuka materi selanjutnya.

5. Video

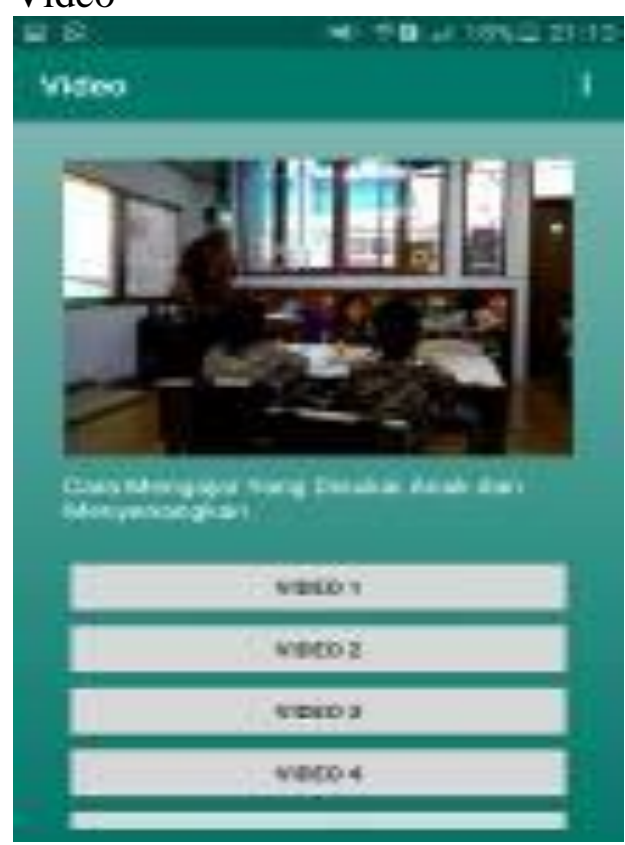

Media ini juga dilengkapi dengan video penerapan berbagai macam strategi pembelajaran. Fitur video ini dimaksudkan untuk mempermudah pemahaman materi dalam media ini. Sehingga siswa dapat mempraktikkan strategi pembelajaran sesuai video yang ditampilkan.

6. Daftar Latihan

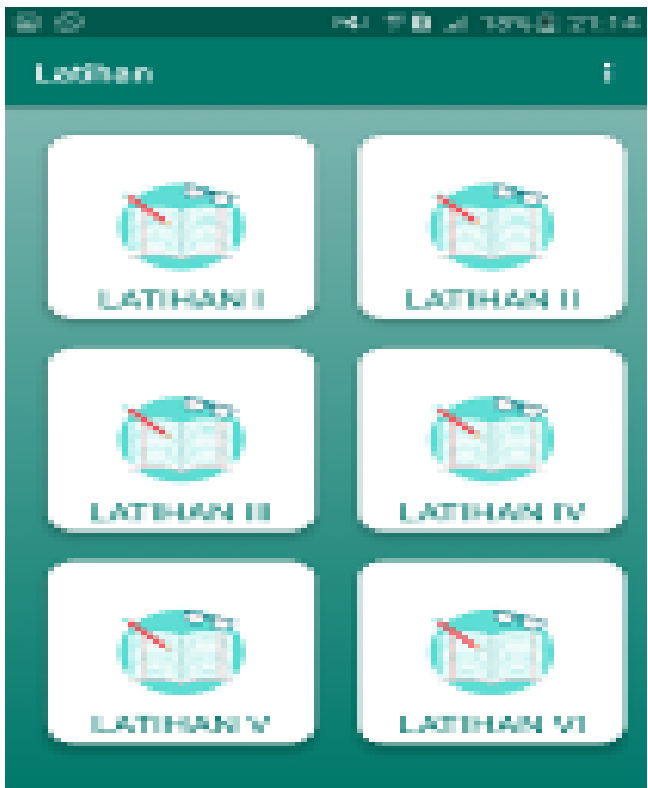

Untuk menguji tingkat pemahaman mahasiswa, pada media ini juga disediakan fitur latihan. Terdapat enam pilihan latihan berupa soal pilihan ganda. Mahasiswa bisa langsung mengerjakan soal yang telah disediakan.

7. Evaluasi

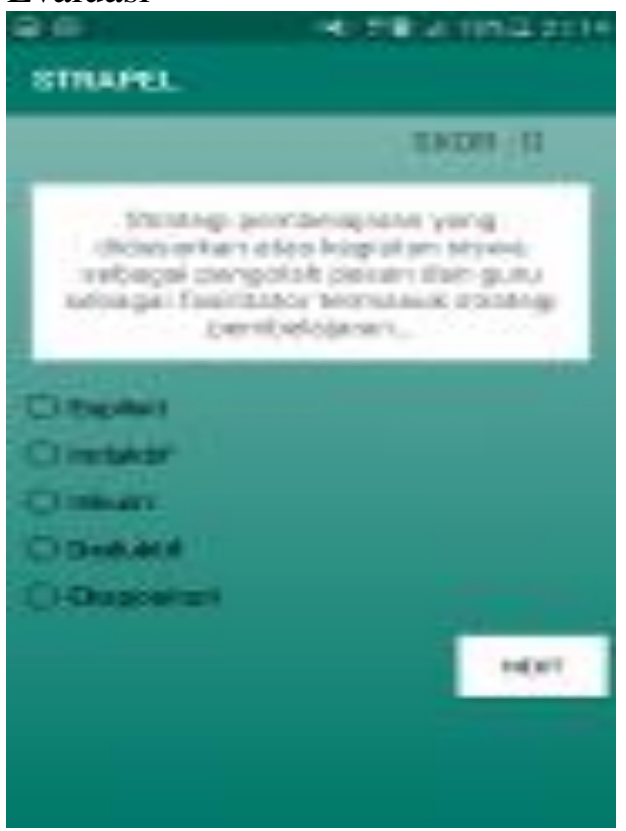


Evaluasi dalam media pembelajaran ini berisi soal-soal pilihan ganda yang harus dikerjakan mahasiswa. Setelah mahasiswa selesai mengerjakan, maka mahasiswa mengetahui hasil (nilai) yang muncul di layar smartphone. Jadi, siswa dapat mengukur kemampuannya sendiri dengan mengerjakan soal yang ada pada aplikasi.

2. Penyajian Data Validasi

Validasi media pembelajaran ini dilakukan oleh validator yang berkompeten pada bidangnya. Data penilaian media pembelajaran tersebut diperoleh melalui tiga tahapan.

a. Tahapan pertama didapat berdasarkan penilaian isi (materi) silabus terhadap media mobile learning berbasis android pada mata kuliah strategi pembelajaran MI/SD oleh dua dosen yang ahli materi terkait strategi pembelajaran. Persentase hasil validasinya berturut-turut sebesar 91\% dan 89\%. Berdasarkan Tabel 2, persentase tingkatan pencapaian tiap-tiap terletak pada tingkatan kualifikasi sangat valid serta valid sehingga media tidak perlu direvisi.

b. Tahap kedua didapat berdasarkan penilaian desain terhadap media oleh dua dosen yang ahli dalam desain pembelajaran. Persentase hasil validasinya berturut-turut sebesar $93 \%$ dan 92\%. Berdasarkan Tabel 2, persentase berada kualifikasi sangat valid.

c. Tahap ketiga didapat berdasarkan penilaian terhadap media oleh dua dosen ahli strategi pembelajaran sebagai pengguna produk. Persentase hasil validasi oleh ahli pembelajaran berturutturut adalah $88 \%$ dan $89 \%$. Berdasarkan Tabel 2, persentase tingkat pencapaian kualifikasi valid dan tidak perlu direvisi.

3. Penyajian Data Hasil Uji Coba Penggunaan Media Mobile Learning Berbasis Android

Partisipan penilitian ini menggunakan dua kelompok yang berdeda (kelas kontrol dan kelas). Kelas B merupakan kelas kontrol dengan total partisipan adalah 44 mahasiswa, sedangkan kelas yang menjadi eksperimen adalah kelas $C$ yang melibatkan 43 mahasiswa.

a. Uji Coba Kelompok Kecil

Peneliti melakukan uji coba kelompok kecil pada 10 mahasiswa. Kriteria yang digunakan untuk pemilihan mahasiswa adalah pemenuhan beragam tingkat kemampuan akademik mahasiswa. Dari 10 mahasiswa tersebut, tiga orang berkemampuan baik, tiga orang berkemampuan menengah, dan empat orang berkemampuan rendah. Persentase hasil validasi pada uji coba ini adalah 88\%. Dengan mengacu Tabel 2, pencapaian persentase berada pada tingkat kualifikasi valid sehingga media tidak perlu direvisi.

b. Hasil Uji Coba Lapangan

Kelas eksperimen digunakan untuk uji coba lapangan yang melibatkan 43 mahasiswa. Hasil uji coba lapangan menunjukkan persentase hasil validasi 86\%. Berdasarkan Tabel 2, pencapaian persentase tingkat kualifikasi valid dan tidak perlu direvisi.

4. $\mathrm{Uji}-\mathrm{T}$

Jika hasil uji-T > 0,05 maka data adalah homogen. Dalam penelitian ini diperoleh nilai Sig. Levene's Test for Equality of Variances sebesar 10,229 > 0,05. Oleh karena itu, peneliti menyimpulkan bahwa varians data antara kelas eksperimen dan kelas kontrol adalah homogen. Sehingga penafsiran tabel output Independent Samples Test berpedoman pada nilai yang ada di dalam tabel "Equal variances assumed". Berdasarkan hasil "Independent Samples Test" pada bagian "Equal variances assumed" diketahui nilai Sig. (2-tailed) adalah $0,024<0,05$. Berdasarkan metode pengambilan keputusan dalam uji independent sample t-test bisa ditarik kesimpulan bahwa $\mathrm{H}_{0}$ ditolak dan $\mathrm{H}_{1}$ diterima. Dengan demikian, terdapat perbedaan yang signifikan antara nilai ratarata hasil belajar mahasiswa kelas kontrol dengan kelas eksperimen. 
Selanjutnya, berdasarkan hasil tabel diperoleh nilai "Mean Difference", yaitu sebesar -3,8319. Nilai ini menunjukkan selisih antara rata-rata nilai hasil belajar mahasiswa yang ada di kelas kontrol dengan rata-rata hasil belajar mahasiswa yang ada di kelas eksperimen atau 79,772-83,605= $\sim 3,8319$ serta selisih perbedaan tersebut bernilai $-7,1551$ sampai $-0,5087 \quad(95 \%$ Confidence Interval of the Difference Lower Upper). Berdasarkan hasil uji-t dapat disimpulkan bahwa media yang dihasilkan memiliki pengaruh yang lebih baik jika dibandingkan dengan pembelajaran konvensional karena nilai rata-rata hasil belajarnya jauh lebih tinggi jika dibandingkan dengan nilai rata-rata hasil belajar menggunakan pembelajaran konvensional.

\section{KESIMPULAN DAN REKOMENDASI}

Peneliti menghimpun dan menyeleksi bahan materi pembelajaran yang relevan serta informasi-informasi aktual dari berbagai sumber. Pengonstruksian materi disesuaikan dengan silabus sehingga dapat mempermudah mahasiswa dalam proses belajar. Penelitian pengembangan ini menghasilkan produk media berbasis mobile learning pada materi mata kuliah strategi pembelajaran. Pengembangan media pembelajaran tersebut bisa dimanfaatkan sebagai informasi pengetahuan bagi mahasiswa dalam hal praktik mengajar ataupun pemahaman materi pada mata kuliah setrategi pembelajaran MI/SD.

Temuan penelitian ini membuktikan bahwa proses pembelajaran yang memanfaatkan media mobile learning berbasis android berpengaruh positif pada nilai hasil belajar mahasiswa. Karena nilai hasil belajar mahasiswa pada kelas eksperimen lebih baik dibandingkan dengan nilai hasil belajar pada kelas kontrol, maka hal ini membuktikan pencapaian tingkat efektivitas media. Penelitian ini menyimpulkan bahwa terdapat perbedaan yang signifikan antara nilai rata-rata hasil belajar mahasiswa kelas kontrol dengan kelas eksperimen.
Produk media ini hanya sebagai suplemen kepada mahasiswa untuk menanamkan konsep pada mata kuliah strategi pembelajaran MI/SD. Pada saat pembelajaran berlangsung sebaiknya uji coba tetap dilaksanakan. Media ini dapat dimanfaatkan secara menyeluruh di kelas dan bisa digandakan untuk pemanfaatan secara lebih luas. Media mobile learning ini memiliki keterbatasan pada pengguna seluler android saja (bukan untuk pengguna perangkat iOS). Oleh karena itu, disarankan kepada pengembang selanjutnya untuk dapat menyempurnakan kekurangan yang ada dari media ini. Ketika pemutaran aktivitas pada media pembelajaran, pengembang sebaiknya memberikan rentang waktu. Penelitian selanjutnya dapat diperluas untuk merancang aplikasi mobile learning pada mata kuliah lainnya.

\section{REFERENSI}

Amelia, R., Rofiki, I., Tortop, H., \& Abah, J. (2020). Pre-service teachers' scientific explanation with e-scaffolding in blended learning. Jurnal Ilmiah Pendidikan Fisika Al-Biruni, 9(1), 33-40.

Angkotasan, N., Tonra, W. S., \& Taib, S. (2019). The excess of Kahoot for preservice teacher as an evaluation tool. International Journal on Teaching and Learning Mathematics, 2(1), 15-20.

Branch, R. M. (2009). Instructional design: The ADDIE approach. Springer Science $\&$ Business Media.

Effendi, M. S. (2013). Desain eksperimental dalam penelitian pendidikan. Jurnal Perspektif Pendidikan, 6(1), 87-102.

Gikas, J., \& Grant, M. M. (2013). Mobile computing devices in higher education: Student perspectives on learning with cellphones, smartphones \& social media. The Internet and Higher Education, 19, 18-26.

Hafidz, R. A., Sumardi, K., \& Komaro, M. (2019). Desain dan pembuatan media pembelajaran mobile learning pada mata pelajaran sistem dan instalasi tata udara. Journal of Mechanical Engineering Education, 6(1), 71-79. 
Hamidi, H., \& Chavoshi, A. (2018). Analysis of the essential factors for the adoption of mobile learning in higher education: A case study of students of the University of Technology. Telematics and Informatics, 35(4), 1053-1070.

Hao, Y., Lee, K. S., Chen, S.-T., \& Sim, S. C. (2019). An evaluative study of a mobile application for middle school students struggling with English vocabulary learning. Computers in Human Behavior, 95, 208-216.

Jeno, L. M., Adachi, P. J. C., Grytnes, J., Vandvik, V., \& Deci, E. L. (2019). The effects of m-learning on motivation, achievement and well-being: A self-determination theory approach. British Journal of Educational Technology, 50(2), 669-683.

Kristanti, F., Ainy, C., Shoffa, S., Khabibah, S., \& Amin, S. M. (2018). Developing creative-problem-solving-based student worksheets for transformation geometry course. International Journal on Teaching and Learning Mathematics, 1(1), 13-23.

Li, K. C., Lee, L. Y.-K., Wong, S.-L., Yau, I. S.-Y., \& Wong, B. T.-M. (2019). The effects of mobile learning for nursing students: an integrative evaluation of learning process, learning motivation, and study performance. International Journal of Mobile Learning and Organisation, 13(1), 51-67.

Mallya, R. K., \& Srinivasan, B. (2019). Impact of mobile learning in the cloud on learning competencies of engineering students. International Journal of Online and Biomedical Engineering (iJOE), 15(9), 80-87.

Motiwalla, L. F. (2007). Mobile learning: A framework and evaluation. Computers \& Education, 49(3), 581-596.

Muchlis, L. S., \& Putra, F. K. (2017). Development of mobile learning basedinteractive multimedia in programming language class at STAIN Batusangkar. Ta'dib, 20(1), 72-84.
Park, Y. (2011). A pedagogical framework for mobile learning: Categorizing educational applications of mobile technologies into four types. The International Review of Research in Open and Distributed Learning, 12(2), 78-102.

Pocatilu, P. (2010). Developing mobile learning applications for Android using web services. Informatica Economica, 14(3), 106.

Rahmi, L. (2019). Perancangan e-module perakitan dan instalasi personal komputer sebagai media pembelajaran siswa SMK. Ta'dib, 21(2), 105-112.

Rosikhoh, D., Mardhiyatirrahmah, L., Abdussakir, A., Abtokhi, A., \& Rofiki, I. (2019). Experienced teachers' perceptions: Math-focused STEAM learning. Abjadia: International Journal of Education, 4(2), 118-128. https://doi.org/10.18860/abj.v4i2.8123

Saputra, M., Abidin, T. F., Ansari, B. I., \& Hidayat, M. (2018). The feasibility of an Android-based pocketbook as mathematics learning media in senior high school. Journal of Physics: Conference Series, 1088(1), 012056.

Skiada, R., Soroniati, E., Gardeli, A., \& Zissis, D. (2014). EasyLexia 2.0: Redesigning our mobile application for children with learning difficulties. Themes in Science and Technology Education, 7(2), 119-135.

Suana, W., Distrik, I. W., Herlina, K., Maharta, N., \& Putri, N. M. A. A. (2019). Supporting blended learning using mobile instant messaging application: Its effectiveness and limitations. International Journal of Instruction, 12(1), 1011-1024.

Suryani, A. I., Anwar, Hajidin, \& Rofiki, I. (2020). The practicality of mathematics learning module on triangles using GeoGebra. Journal of Physics: Conference Series, 1470(1), 012079. https://doi.org/10.1088/17426596/1470/1/012079 


\section{Article Metadata:}

Hanifah, N.H. Rofiki, I. Sedayu, A. Hariyadi, M.A. (2020). Mobile Learning in Elementary School/Islamic Elementary School Learning Strategy Subject: A Development Research. Ta'dib, 23 (1), 123-132.

http://dx.doi.org/10.31958/jt.v23i1.1704

Keywords: Development, Mobile Learning, Android, Learning Strategy, Learning Media, ADDIE

Coresponding author: Imam Rofiki, Universitas Islam Negeri Maulana Malik Ibrahim Malang, imam.rofiki@uin-malang.ac.id 